TITLE:

\title{
PYCNOGONIDA OF THE JAPANESE ANTARCTIC RESEARCH EXPEDITIONS 1956-1958
}

$\operatorname{AUTHOR}(\mathrm{S})$ :

Utinomi, Huzio

CITATION:

Utinomi, Huzio. PYCNOGONIDA OF THE JAPANESE ANTARCTIC RESEARCH EXPEDITIONS 1956-1958. SPECIAL PUBLICATIONS FROM THE SETO MARINE BIOLOGICAL LABORATORY 1959, 1(8): 1-12

ISSUE DATE:

1959-10

URL:

http://hdl.handle.net/2433/176438

RIGHT: 
SPECIAL PUBLICATIONS FROM THE SETO MARINE BIOLOGICAL LABORATORY

(Contributions from the Seto Marine Biological Laboratory, No. 341.)

\author{
BIOLOGICAL RESULTS \\ OF
}

THE JAPANESE ANTARCTIC RESEARCH EXPEDITION

8.

\title{
PYCNOGONIDA OF THE JAPANESE ANTARCTIC RESEARCH EXPEDITIONS 1956-1958
}

BY

\section{HUZIO UTINOMI}

SETO MARINE BIOLOGICAL LABORATORY

SIRAHAMA, WAKAYAMA-KEN, JAPAN

SIRAHAMA, WAKAYAMA-KEN

JA P A N

DECEMBER 1959 
SPECIAL PUBLICATIONS FROM THE SETO MARINE BIOLOGICAL LABORATORY

(Contributions from the Seto Marine Biological Laboratory, No. 341.)

BIOLOGICAL RESULTS

$\mathrm{OF}$

THE JAPANESE ANTARCTIC RESEARCH EXPEDITION

8.

\section{PYCNOGONIDA OF THE JAPANESE ANTARCTIC RESEARCH EXPEDITIONS 1956-1958}

$\mathrm{BY}$

\section{HUZIO UTINOMI}

SETO MARINE BIOLOGICAL LABORATORY

SIRAHAMA, WAKAYAMA-KEN, JAPAN

SIRAHAMA, WAKAYAMA-KEN

$$
\text { J A P A N }
$$

DECEMBER 1959 
THIS SERIES contains THE BIOLOGICAL RESULTS OF THE JAPANESE ANTARCTIC RESEARCH EXPEDITION and is published by the Seto Marine Biological Laboratory. Parts will appear at irregular intervals as they become ready.

PRINTED IN JAPAN

BY NIPPON PRINTING AND PUBLISHING Co., Ltd.

HUKUSIMA, OSAKA. 
THE Antarctic pycnogonid fauna is comparatively well known to a large extent mainly through the works of HoDGSON $(1902,1907)$, BOUvIER (1906, 1913), Calman (1915), Loman (1923), GoRdon (1932, 1938, 1944), HedGPeti (1950) and FAGE (1952).

The pycnogonid materials brought back by the Japanese Antarctic Research Expeditions are, however, very few in number. During two cruises to the Antarctic region only three species were procured, each represented by a solitary specimen. It is probable that the apparent deficiency is due to the fact that the two Japanese expeditions devoted less attention to the biological investigations.

Among the collection, one was obtained by Mr. Hiroshi Toya of the Tokyo Metropolitan University who joined the expedition as a geographer during the first cruise (1956-57). The other two materials were collected by Dr. Riozo Yosil of the Yoshida College, Kyoto University who was a biologist to the second cruise (1957-58).

All these materials will be kept in the National Science Museum, Tokyo.

It is my pleasant duty to express my appreciation to both the members of expeditions mentioned above for the opportunity of examining these materials.

\section{Deseription of the Species}

\section{Family NYMPHONIDAE}

1. Nymphon soyae Utinomi, n. sp.

(Figs. 1-2)

Material. One immature male, holotype. Gunnerus Bank, $590 \mathrm{~m}$. February 1, 1958. Dr. R. YosII coll.

Description. - Trunk slender, smooth, elongate, distinctly segmented. Lateral processes also slender, elongate, widely spaced by about twice of their own diameter. Cephalic segment about three-tenths of the length of trunk, neck not very long. Ocular tubercle low, rounded at tip, situated on neck; eyes distinct but not well-pigmented.

Bases of ovigers in contact with the first pair of lateral processes. Proboscis short, as long as neck, truncate at end. Abdomen notched at end, shorter than the last segment of trunk, directed obliquely upwards. 
Chelifores with strongly diverging scapes. Chelae slender, a little shorter than scape, with fingers abruptly curved distally, a little longer than palm. Movable finger beset with 15 spinules, but immovable finger with 9 spinules.

Palps slender, second joint the longest, its end not reaching the anterior end of proboscis. Third joint about two-thirds as long as second, fourth joint a little shorter than third fifth joint a little longer than fourth; these terminal three joints loosely setose.

Ovigers of GoRDON's type I, long, uniformly slender, feebly setose, 10-jointed ; terminal claw about one-half as long as tenth joint and armed with 4 slender spinules. Total number of denticulate spines 16, arranging in the manner of $5: 3: 3: 5$.

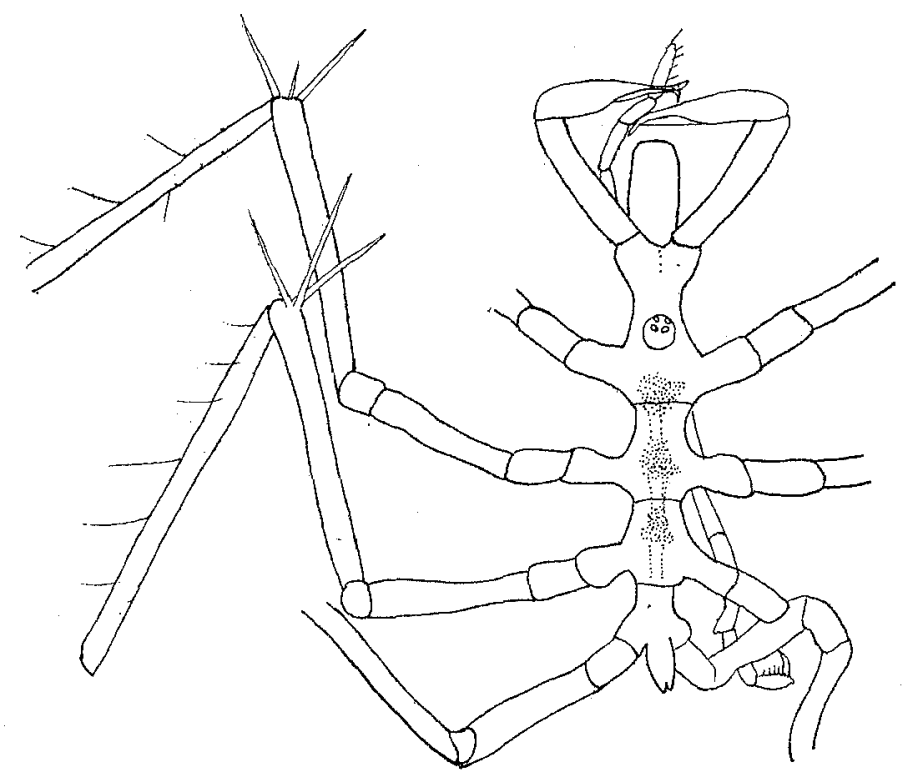

Fig. 1. Nymphon soyae, n. sp. Immature male, holotype. $\times 27$.

Legs long, very slender, first coxa subequal to lateral processes in length, second coxa the longest. Femur longer than coxae combined together, gradually wider distally and armed with three prominently large setae dorsally at its distal end. Both tibias bearing long, slender setae dorsally, either longer and more slender than femur. Tarsus, propodus and claw elongated, setose on both sides; claw slightly shorter than propodus. Auxiliaries absent.

Remarks. - This specimen, though immature, belongs to the group I of the genus Nymphon following GoRDON's systematization based on the character of the male oviger (GoRDON, 1932, p. 27). The closest relatives in Antarctic waters 
Pycnogonida of the Japanese Antarctic Research Expeditions 1956-1958

are Nymphon proceroides Bouvier (1913) and N. tenuipes Bouvier (1913). This animal resembles $N$. tenuipes in having 3 long setae at the distal end of femur of all legs, but has smaller number of spinules on each finger of chela (less than 20) as in $N$. proceroides. It resembles also $N$. natalense FLYNN (1928) from South Africa in the conformation of the body and legs, but the latter belongs to GoRDon's group II, having a clavate fifth joint in the male oviger.

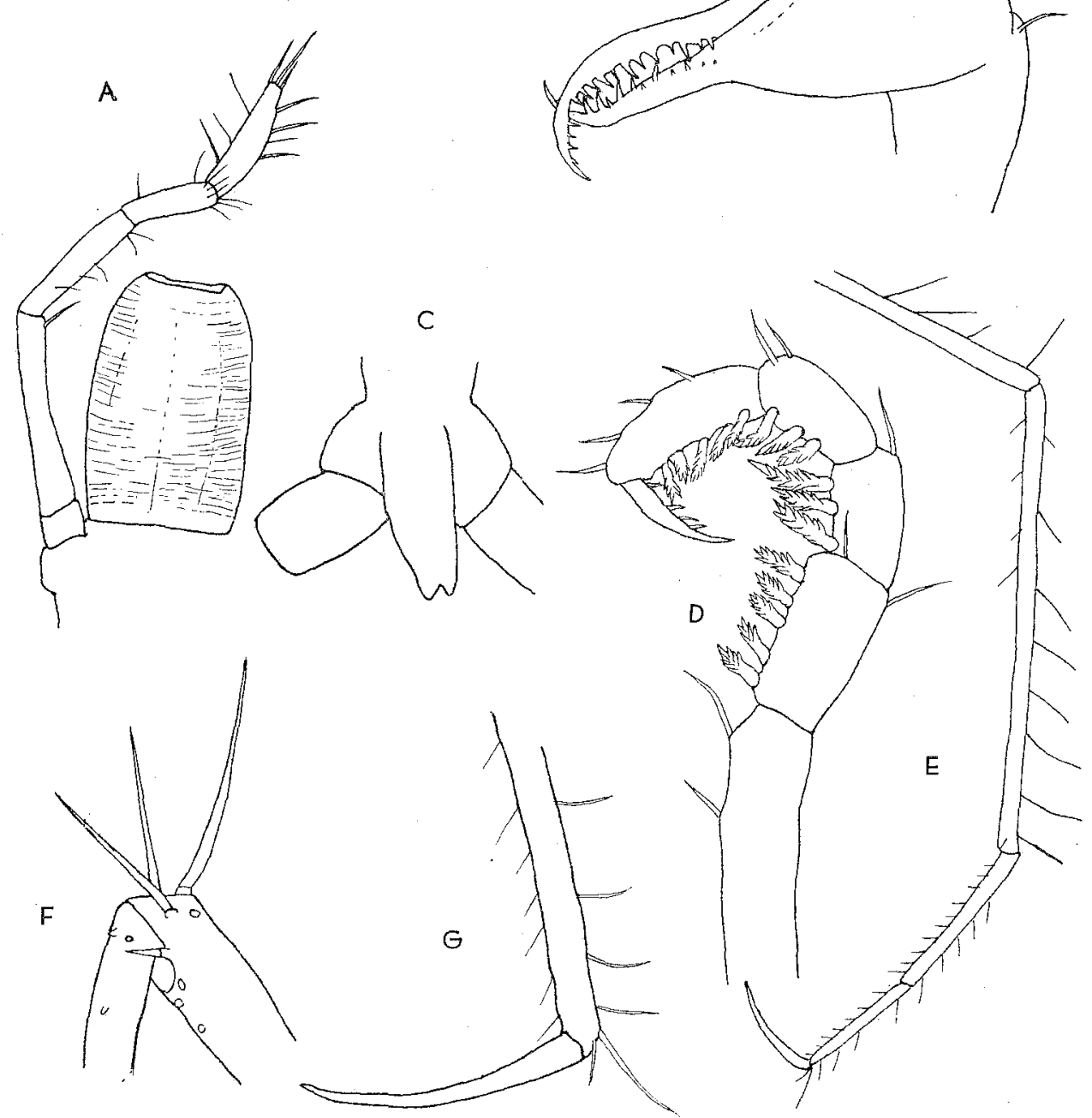

Fig. 2. Nymphon soyae, n. sp.

A, palp and proboscis. $\times 72 . \mathrm{B}$, chela. $\times 87 . \mathrm{C}$, abdomen. $\times 72 . \mathrm{D}$, terminal segments of oviger. $\times 135$. E, distal segments of second leg. $\times 25$. F, distal end of femur, bearing three large setae. $\times 72$. G, terminal claw of legs. $\times 72$. 
Measurements of the male, holotype (in $\mathrm{mm}$ ).-

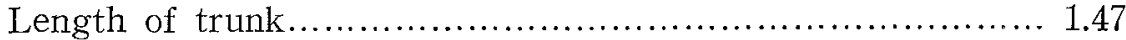

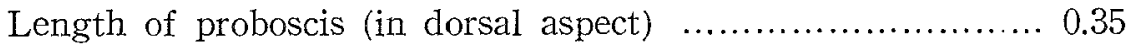

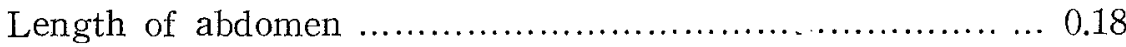

Length of scape........................................... 0.59

Length of chela ............................................... 0.53

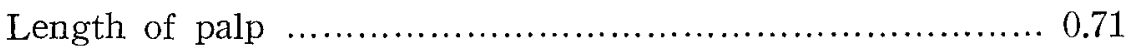

Length of lateral processes................................... 0.18

Width of trunk (betw. 1st and 2nd lat. processes) ........... 0.18

First leg

Coxa 1 ................................................ 0.24

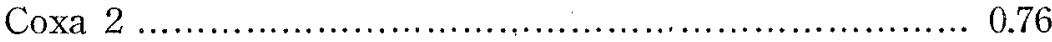

Coxa 3 ................................................. 0.15

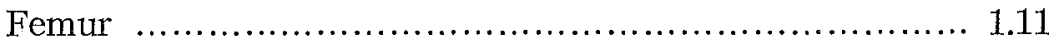

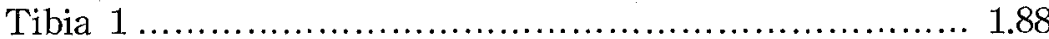

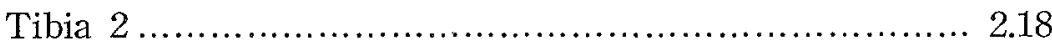

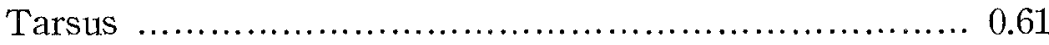

Propodus ................................................... 0.47

Claw .............................................................. 0.41

\section{Nymphon proximum CALMAN}

(Figs. 3-5)

Nymphon proximum: Calman, 1915, p. 34, fig. 6; GoRDON, 1944, p. 28, fig. 6a-b.

Material. - One female. West of Cape Cook, $590 \mathrm{~m}$. Bottom: sandy mud. February 1, 1958. Dr. R. YosII coll.

Description.-This female specimen is possibly referable to Nymphon proximum. CALMAN which was originally described on a male specimen.

Trunk compact, all lateral processes almost in contact proximally, with no neck. Cephalic segment wider than long, deeply notched in the middle of front, dividing into two strong cephalic lobes.

Ocular tubercle about three times as high as wide, somewhat inclined forwards; eyes large, situated at apex. There are a pair of stout setae on the mid-dorsal surface of segments $1-2$, but three on segment 3 .

Proboscis very stout, cylindrical, about as long as scape of chelifores.

Abdomen horizontal, fusiform, about two-fifths as long as trunk.

Chelifore stout, scape armed above, especially on inner side, with strong spiniform setae. Chela rather short, with palm a little longer than immovable finger which forms an angle of roughly $120^{\circ}$ with its inner edge; outer face setose. Movable finger which is armed with 18 spinules, abruptly curved 
Pycnogonida of the Japanese Antarctic Research Expeditions 1956-1958

distally and longer than immovable finger which is armed with 12 spinules.

Palp with second segment longer by one-half than third which is longer than the sum of fourth and fifth; finely setose distally.

Oviger 12-jointed, of almost uniform diameter throughout ; first three segments longer than fourth which is subequal to fifth. Number of denticulate spines on each of the terminal four segments is $4: 3: 2: 3$. Terminal claw rather shorter than tenth segment, armed with five spinules.

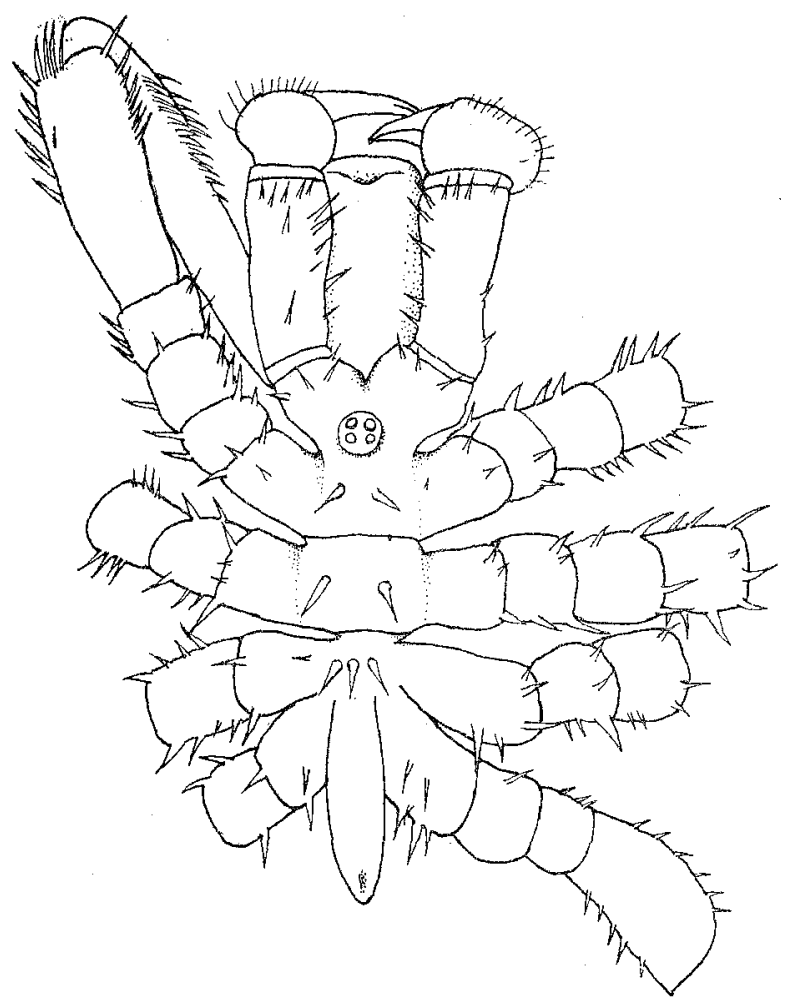

Fig. 3. Nymphon proximum CALMAN, female, in dorsal aspect. $\times 10$.

Legs rather short in proportion to the size of trunk, very stout, but tapering rapidly from the end of first tibia. All coxae and femur like lateral processes armed with stout roughened spines rather irregularly. First tibia as long as femur, longer and wider than second tibia; on both tibiae spinose setae whose length are less than the diameter of each segment are closely set in two dorsal, two lateral and one ventral rows. Tarsus short, roughly one-third as long as second tibia and one-half as wide as the latter. Propodus more slender and a little longer than tarsus; both segments setose on dorsal and ventral edges 


\section{Huzio UTINOMI}

alone. Terminal claw robust, about one-third as long as propodus; auxiliaries rather rudimentary.

Remarks. - In the holotype male (CALMAN, 1915, p. 34), a pair of stout setae on a tubercle in middle of each of three somites dorsally. In this specimen, however, such a marked tubercle is not found, yet 2 or 3 spiniform setae are

A
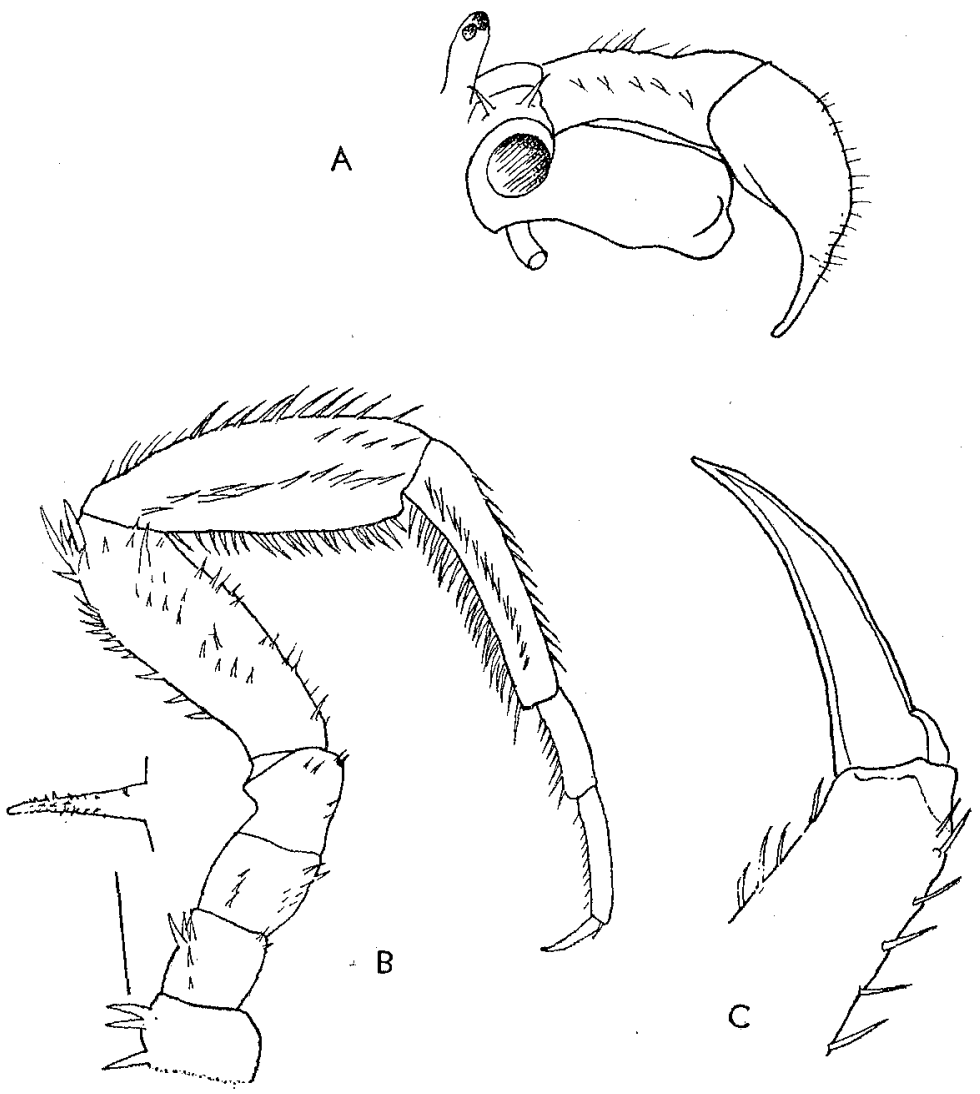

Fig. 4. Nymphon proximum Calmax.

A, chelifore and proboscis, in lateral aspect. $\times 13$. B, second leg $\times 13$, with roughened stout seta more highly magnified. $C$, terminal claw with auxiliary claw. $\times 80$.

present on the flattened dorsal surface in each segment of the trunk; this character is not mentioned by GoRDON (1944) for the specimens of both sexes from the B.A.N.Z.A.R.E. collections. Otherwise the material agrees in general with CALMAN's original description.

Distribution. - Originally recorded from 'Terra Nova' Station 295 (Ross Sea, 190 fathoms) and later from 'B.A.N.Z.A.R.E.' Stations $30\left(66^{\circ} 48^{\prime}\right.$ S., $71^{\circ} 42^{\prime}$ E., 
Pycnogonida of the Japanese Antarctic Research Expeditions 1956-1958

$540 \mathrm{~m}), 34\left(66^{\circ} 21^{\prime}\right.$ S., $58^{\circ} 50^{\prime}$ E., $\left.603 \mathrm{~m}\right), 39\left(66^{\circ} 10^{\prime}\right.$ S., $49^{\circ} 41^{\prime}$ E., $\left.300 \mathrm{~m}\right)$ and 40 $\left(66^{\circ} 12^{\prime}\right.$ S., $49^{\circ} 37^{\prime}$ E., $\left.300 \mathrm{~m}\right)$.

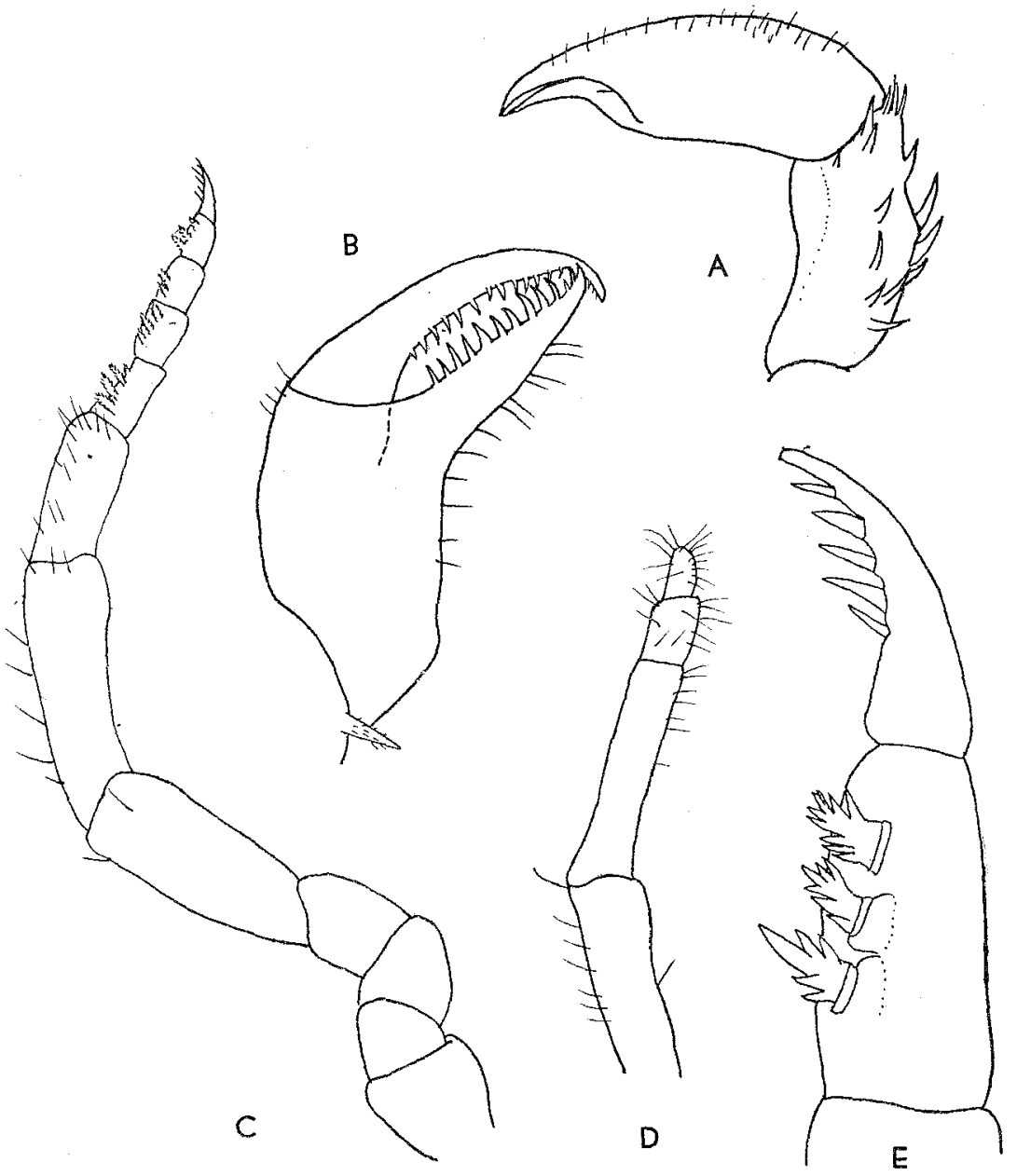

Fig. 5. Nymphon proximum CALMAN.

A, chelifore in posterior aspect. $\times 18$. B, chela, showing spinules of fingers. $\times 27$. C, female oviger. $\times 27$. D, distal part of palp. $\times 27 . \mathrm{E}$, terminal segment and claw of oviger. $\times 150$.

Measurements of a female specimen (in $\mathrm{mm}$ ).-

Length of trunk ............................................ 4.00

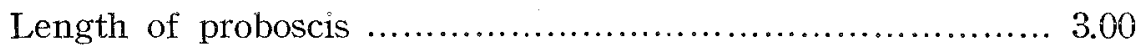

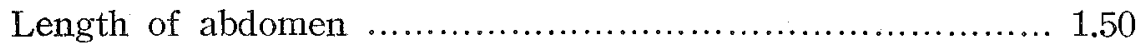

Width of trunk (betw. 1st and 2nd lat. processes) ............ 1.00

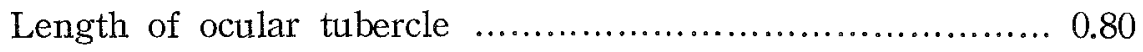




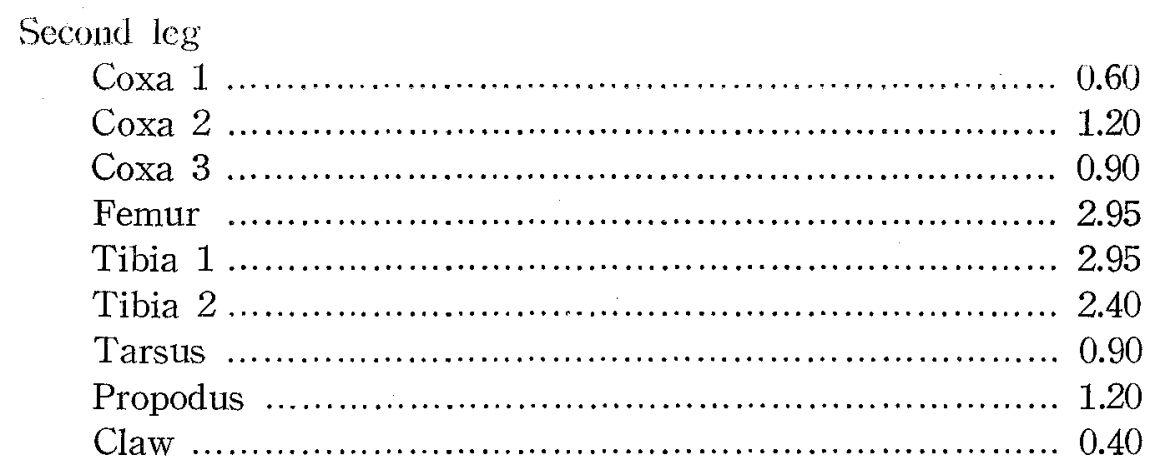

Family COLOSSENDEIDAE

\section{Colossendeis longirostris GORDON}

(Fig. 6)

Colossendeis longirostris: GORDON, 1938, p. 9, fig. 1.

Material. - A large specimen (? male). South-west coast of Ongul Island, $2.5 \mathrm{~m}$. February 11, 1957. Mr. Hiroshi ToyA coll.

Description. - The specimen, when received by me, is dried and colored dark brown uniformly.

Trunk non-segmented, lateral processes widely separated by about their own diameter. The greatest width between the second and third lateral processes is approximately one-fourth the length of trunk. Ocular tubercle low conical, about as high as wide, eyes inconspicuous.

Proboscis much elongate, longer than trunk, cylindrical, slightly dilated anterior to the proximal one-third; the base attached to cephalic segment about two-thirds as wide as the distal end.

Abdomen short, cylindrical instead of clavate, but constricted at base.

Palp slender, considerably longer than proboscis; second joint the longest; fourth joint is slightly more than one-half as long as second; fifth joint about one-half as long as sixth; the sum of fifth and sixth joints is shorter than fourth. Terminal three joints are missing.

Oviger in contact with the base of palps long, robust, with fourth and sixth joints subequal in length; spines on the four terminal joints are roughly arranged in four rows; a large curved spine at the distal end of terminial joint opposed to the terminal claw, forming a subchelate structure.

Legs, the second to fourth only remained, lack the distal portion unfortunately.

Remarks. - This specimen, though incomplete, may be referable to Colossendeis longirostris GORDON in the shape of the proboscis much longer than the trunk 
Pycnogonida of the Japanese Antarctic Research Expeditions 1956-1958

and the characteristic subchelate termination of the oviger rather than to any related Antarctic species such as C. tortipalpis (GORDON, 1932, p. 12) and $C$. ausiralis (Hodgson, 1907, p. 59; Bouvier, 1913, p. 63; CALMAN, 1915, p. 14 ; GORDON, 1932, p. 15, 1938, p. 10, 1944, p. 10).

Distribution. - This is the second record of this species. The holotype was collected from the Station $5\left(64^{\circ} 34^{\prime}\right.$ S., $127^{\circ} 8^{\prime}$ E., 1700 fathoms $)$ during the Australasian Antarctic Expedition 1911-14.
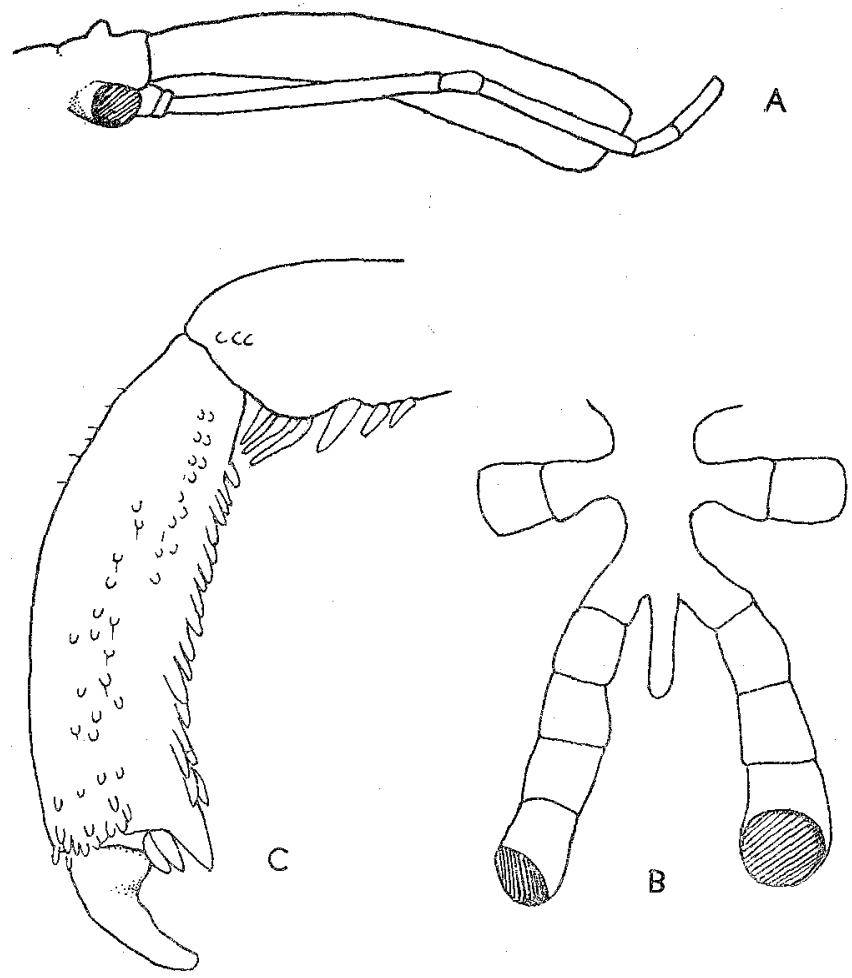

Fig. 6. Colossendeis longirostris GORDON.

A, proboscis and part of cephalic segment, right side. $\times 2$.

$B$, posterior part of trunk with abdomen and legs. $\times 2$.

$\mathrm{C}$, terminal segments of oviger. $\times 10$.

Measurements of a specimen (probably male) (in mm).-

Length of trunk 23

Length of proboscis 36

Length of abdomen 6

Width of trunk (betw. 2nd and 3rd lat. processes) ............. 6

Greatest diameter of proboscis ............................... 8

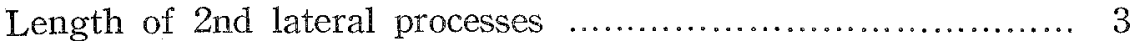




\section{REFERENCES}

Bouvuer, E. L. 1906. Pycnogonides du "Français". Expédition Antarctique Française (1903-1905), 60 pp., 48 figs., 3 pls.

_ 1913. Pycnogonides du 'Pourquoi-Pas?' Deuxième Expedition Antarctique Française (1908-1910), VI, pp. 1-169.

CalmaN, W. T. 1915. Pycnogonida. British Antarctic ("Terra Nova") Expedition, 1910: Natural History Report, Zoology, vol. III, no. 1, pp. 1-74, 22 figs.

FAGE, L. 1952. Pycnogonides de la Terre Adélie. Bull. Mus. Nat. Hist. Paris, Série 2, vol. 24, no. 3, pp. 263-273, 2 figs.

FLYNN, T. T. 1928. The Pycnogonida of the Marine Survey of South Africa. Fish. and Mar. Biol. Surv., S. Afr., Report No. 6 for the year 1927-1928, Spec. Rep., no. 1, pp. 1-36, 21 figs.

Gordon, I. 1932. Pycnogonida. Discovery Reports, vol. VI, pp. 1-138, 75 figs.

- 1938. Pycnogonida. Australasian Antractic Expedition 1911-14, Sci. Rep., Series C-Zool. and Bot., vol. II, pt. 8, pp. 5-40, 8 figs.

1944. Pycnogonida. B. A. N. Z. Antarctic Research Expedition 1929-1931, Reports-Series B (Zool. and Bot.), vol. V, pt. 1, pp. 1-72, 27 figs.

Hedgpeth, J. W. 1950. Pycnogonida of the United States Navy Antarctic Expedition, 1947-48. Proc. U. S. Natl. Mus., vol. 100, no. 3260, pp. 147-160, 19 figs.

Hodgson, T. V. 1902. Crustacea. Roport on the collections of natural history made in the Antarctic regions during the voyage of the "Southern Cross." London, pp. 228-261, pls. 29-49. (Pycnogonida: pp. 256-258, pl. 49.]

1907. Pycnogonida. National Antarctic Expedition 1901-1904, Natural History, vol. III Zool, and Bot., pp. 1-72, pls. 1-10.

LOMAN, J. C. C. 1923. The Pycnogonida of the Swedish Antarctic Expedition (1901-1903). Further Zool. Res. Swedish Antarctic Expedition 1901-1903, vol. I, no. 2, pp. 1-41, figs. A-G. 


\section{BIOLOGICAL RESULTS}

\section{$\mathrm{OF}$}

\section{THE JAPANESE ANTARCTIC RESEARCH EXPEDITION}

1. Tanita, Senji: Sponges. 1959.

2. NAKasero, Kojiro: On Superfamily Liosphaericae (Radiolaria) from sediments in the sea near Antarctica (On Radiolaria from sediments in the sea near Antarctica. Part 1). 1959.

3. Hirano, Minoru: Notes on some algae from the Antarctic collected by the Japanese Antarctic Research Expedition. 1959.

4. HataI, Kotora: A new rhynchonellid (Brachiopoda) from Antarctica. 1959. $¥ 50$

5. TokiokA, Takasi : Amaroucium erythraeum Michaelsen, a compound ascidian from the Cape Province. 1959.

6. YosIr, Riozo: Collembolan fauna of the Cape Province, with special reference to the genus Seira Lubbock. 1959.

$¥ 150$

7. Gamo, Sigeo: On a cumacean Crustacea (Diastylis corniculatus Hale) obtained by the Second Japanese Antarctic Research Expedition (1957-58). 1959.

$¥ 50$

8. Utinomi, Huzio: Pycnogonida of the Japanese Antarctic Research Expeditions 19561958. 1959. 